\title{
SEDAM STOLJEĆA OTOKA MRKANA U NASLOVU TREBINJSKIH BISKUPA
}

\author{
Ivica PULJIĆ \\ Župni ured Neum \\ Trg Gospe od Zdravlja 1 \\ $\mathrm{BiH}-88390$ Neum \\ E-pošta: don.ivica.puljic@tel.net.ba
}

\author{
UDK $272-773(497.5 / .6) " 10 / 16 "$ \\ Izvorni znanstveni rad \\ Primljeno: 6. travnja 2015 \\ Prihvaćeno: 6. svibnja 2015
}

\section{Sažetak}

Trebinjska biskupija utemeljena je u drugoj polovici X. stoljeća. Kad su početkom XIV. stoljeća srpski vladari prognali njezina biskupa, našao je on utočište u bivšem benediktinskom samostanu na otočiću Mrkanu. Otada trebinjski biskupi nose i mrkanski naslov. Predmet ove studije jest istraživanje kada i kako se taj progon zbio i kako se kroza stoljeća ustalio današnji naziv Trebinjsko-mrkanska biskupija.

Ključne riječi: Trebinje, Mrkan, Trebinjsko-mrkanska biskupija, Dubrovnik. 


\section{Prva stoljeća Trebinjske biskupije}

Papa Benedikt VIII. (1012.-1024.) u buli od 27. rujna 1022. ${ }^{1}$ potvrđuje metropolitanska prava dubrovačkoga nadbiskupa onako kako je to odredio papa Grgur (V., 996.-999.). Među sufraganskim biskupijama navodi se i Trebinjska. Očito je, dakle, Trebinjska biskupija ušla kao već postojeća u sastav nove Dubrovačke metropolije. Budući da nije spomenuta na splitskim saborima 925. i 928., ${ }^{2}$ utemeljena je najvjerojatnije u drugoj polovici X. stoljeća kada je kneževina Trebinje $^{3}$ (latinski Tribunia, u dokumentima istočne provenijencije Travounia ili Travunja, u aktima kancelarije Bosanskoga kraljevstva Trebinje) postala ne samo neovisna o Bizantu i o njemu podložnom Dubrovniku, ${ }^{4}$ nego je prema Ljetopisu kojega je na- pisao Presbyter Diocleatus neko vrijeme igrala i vodeću ulogu u Crvenoj Hrvatskoj, ${ }^{5}$ što je bila prigoda za uspostavu biskupije. Prvotne granice biskupije poklapale su se najvjerojatnije s granicama pokrajine Trebinje pa nije nevjerojatna tvrdnja da se, kao i pokrajina, prostirala u početku umalo do zidina Dubrovnika. ${ }^{6}$ Porfirogenet piše da je zemlja Trebinjana i Konavljana jedna zemlja. ${ }^{7}$ On navodi gradove: "Terbounia, Ormos, Risena, Lukavetai, Zetlivi",8 a Dukljanin žup(anij)e: "Libomir, Vetanica (Fatnica), Rudina, Crusceviza, Vrmo (Korjenići), Rissena, Draceviza, Canali, Gernoviza (Župa)". Dukljanin piše da je Belo-Pavlimir iznenada umro "u jednom gradu Tribunije" i pokopan u crkvi sv. Mihaela u istom gradu š to je najvjerojatnije prva katedrala biskupije koja je i danas pod zaštitom sv. Mihaela.

1 Državni arhiv Dubrovnik (dalje: DAD), Bečka skupina, b.b.; JAKov STIPIŠIĆ - MiLjen Šamšalović (sakupili), Marko Kostrenčić (prir.), Codex diplomaticus regni Croatiae, Dalmatiae et Slavoniae (dalje: Cod. dipl.), I., Zagreb, 1967., str. 61-62. Druge sveske priredio je Tadija Smičiklas.

2 Ivica Puljıć, "Prva stoljeća trebinjske biskupije", u: Tisuću godina trebinjske biskupije (dalje: Tisuću godina), Sarajevo, 1988., str. 47-80.

3 Ante Figurić, Trebinje nekada i danas, Ljubljana, 1930.; Vojislav J. Korać, Trebinje, I., Trebinje, 1966.; Đuro Tošić, Trebinjska oblast u srednjem vijeku, Beograd, $1988 . ;$ Esad Arnautović, "Oblici imena oblasti i grada Trebinja u istorijskim izvorima", u: Tribunia, I., Trebinje, 1975., str. 91-99.

4 Konstantin Porfirogenet, O upravljanju carstvom, prijevod i komentari Nikola ToMAšIĆ, Konstantin Porfirogenet - O upravljanju carstvom, Zagreb, 2003., str. 64, 242 (dalje: K. Porfirogenet, nav. dj.).

5 Ferdo Šišić, Letopis popa Dukljanina, Beograd, 1928., str. 320 i 322 (dalje: F. Šišić, Letopis); Vladimir Mośin, Ljetopis popa Dukljanina, Zagreb, 1950., str. $71-72$ (dalje: V. Mošin, Ljetopis); Đuro Tošıć, Trebinjska oblast, str. 73, bilj. 24. Po svoj prilici dio Ljetopisa zapravo je izgubljena trebinjska kronika!

6 "... ad montem qui situs est ante ciuitatem Ragusinum." Cod. dipl., IV., str. 483.

7 K. Porfirogenet, nav. dj., str. 89, 280-281. O povijesti Konavala: Konavoski zbornik, osobito I., Dubrovnik, 1982., str. 13-104.

8 K. Porfirogenet, nav. dj., (poglavlje 34), str. 89-90, 280-281.

9 F. Šıšıć, Letopis, str. 322, 326; V. Mošın, Ljetopis, str. 72, 75. 


\section{Vrijeme progona trebinjskih biskupa na otok Mrkan}

Krajem XII. stoljeća veliki raški župan Nemanja osvaja katoličke primorske pokrajine pa i Trebinje. ${ }^{10}$ Prognao je biskupa iz Stona. Iako trebinjski biskup nije protjeran, zlatna su vremena potpune slobode nakon nekoliko stoljeća minula.

\subsection{Prvi progon trebinjskoga biskupa}

Nemanjin sin Rastko - Sava kao metropolit i organizator Srpske pravoslavne crkve utemeljio je u Raškoj šest novih pravoslavnih episkopija te po jednu u Duklji i Stonu, dok je Trebinje zaobišao. Od toga vremena skoro svi srpski kraljevi vrše više ili manje snažan pritisak da u strukture Srpske pravoslavne crkve uklope prije svega katolike slavenske službe Božje, a da katoličkim biskupima ostave samo neslavensko pučanstvo. ${ }^{11}$

Do prvoga progona trebinjskoga biskupa došlo je polovicom XIII. stoljeća. Papa Inocent IV. (1243.-1254.) izuzeo je 1246. godine bosanskoga biskupa iz Dubrovačke metropolije i podvrgao ga Kaloči ${ }^{12}$ čime je Dubrovačka metropolija ugrožena jer joj je kao sufraganska ostala samo Trebinjska biskupija. Zato je nadbiskup
Ivan (1238.-1252.) krenuo na put da od pape isposluje ukinuće Barske metropolije i podvrgavanje njezinih sufragana Dubrovniku. Na tom putu je u Veneciji za trebinjskoga biskupa posvetio lokrumskoga opata Salvija (Salvius, Slavius). ${ }^{13}$ Kobno je bilo to što je papa Inocent IV. u sporu Dubrovnika i Bara za metropolitansko pravo delegirao upravo trebinjskoga biskupa kao svoga legata. Dubrovački nadbiskup je pred papom dobio parnicu. Kralj Stefan Uroš I. (1243.1276.) iskoristio je opće nezadovoljstvo katoličkih prelata i puka u državi. Kad je u Baru pročitana odluka da se Bar (crkveno) treba podvrći Dubrovniku, revoltirano je prisutno mnoštvo čak vikalo: "Quid est papa? Dominus noster Urosius est nobis papa!"14 Uroš je 1252. godine napao Dubrovnik, prognao trebinjskoga biskupa, a dubrovačkom je nadbiskupu poručeno da ni on ni papa nemaju nikakve vlasti u njegovu kraljevstvu jer ono ima svoje nadbiskupe, jedne Slavene i druge Latine, i svoga papu koga moraju i jedni i drugi slušati! Iz dokumenata spora vidi se da je i Urošev prethodnik, njegov brat kralj Vladislav (1234.-1243.), koji je bio u lošim odnosima s Dubrovnikom, ${ }^{15}$ jer su pružili utočište njegovu prethodniku kralju Radoslavu (1228.-1234.), bio neprijateljski raspoložen prema

10 Nemanja je Trebinje osvojio oko 1186. godine. Đ. Tošıć, Trebinjska oblast, str. 77.

11 Konstantin Jireček, Istorija Srba, II. (koristimo prijevod Jovana Radonića, Beograd, 1981.), str. 73.

12 Cod. dipl., IV., str. 277-279, 322.

13 Salvius se kao opat spominje na Lokrumu 1239. i 1245. Cod. dipl., IV., str. 89, 176.

14 Stanoje Stanojević, Borba za samostalnost Katoličke Crkve u nemanjićkoj državi, Beograd, 1912., str. 121, bilj. 2; Vladimir Ćorović, Istorija Srba, I., Beograd, 1989., str. 157-158.

15 K. JIREČEK, nav. dj., I., str. 172. 
Katoličkoj crkvi. On je ovom prigodom izrekao užasne pogrde o papi ${ }^{16}$

Kako su Dubrovčane napustili svi saveznici u ovom ratu, mir su sklopili 1254. godine pod vrlo nepovoljnim uvjetima. Dubrovački je nadbiskup izgubio svaki utjecaj u srpskoj državi. ${ }^{17}$ A budući da je kralj Uroš nastojao podvrći sebi i Dubrovnik isto kao Bar i Kotor, odnosi su bili trajno napeti i nije bilo mogućnosti da se prognani trebinjski biskup vrati u biskupiju. ${ }^{18}$ Spominje se na Lokrumu kao "biskup opat". ${ }^{19}$ Papa Grgur X. (1271.-1276.) ne prihvaća 1275 . godine molbu da se trebinjskoga biskupa postavi na jednu upražnjenu biskupsku stolicu u Apuliji, obrazlažući to da ništa manje "Tribunien. quam eidem Iuvenacien. Eclesiis potest existere fructuosus". ${ }^{20}$ Papa Ivan XXI. (1276.-1277.) ipak ga je sljedeće godine premjestio na dubrovačku nadbiskupsku stolicu, ${ }^{21}$ pa je tako Trebinjska biskupija ostala upražnjena.

\subsection{Obnova Trebinjske bisku- pije nakon 1286. godine}

Kada je kralja Uroša I. kod Gacka 1276. godine pobijedio sin Stefan Dragutin (1276.-1316.), ${ }^{22}$ prilike su se u državi prema katolicima korjenito promijenile. On je darovao katolkinji majci kraljici Jeleni u izravnu upravu katoličko primorje od Dubrovnika do Skadra. Dragutin je od 1282. godine uzeo za suvladara mlađega brata Stefana Uroša II. Milutina (1282.-1321.). Kraljica Jelena započela je opću obnovu vjerskih prilika u primorju. Međucrkveni odnosi u njezino vrijeme bili su dobri. Arhiepiskop Danilo hvali njezinu dobrotu, darežljivost, pobožnost i primjeran život. ${ }^{23}$ Obnavljala je i gradila crkve $^{24}$ i katolicima i pravoslavcima pa je i kod jednih i kod drugih ostavila najljepšu uspomenu. U dogovoru s barskim nadbiskupom ustanovila je biskupiju u Sapi na Skadarskom jezeru. Obnovila je stradalo Trebinje $\mathrm{u}$ tatarskoj provali te $\mathrm{u}$ nje-

16 Cod. dipl., IV., str. 420, 445-447, 494-495, 500-507; S. STAnojević, nav. dj., str. 136-137.

17 K. JiREČEK, nav. dj., I., str. 179.

18 Dubrovčani su utvrđivali gradske zidine. K. JiREčEK, nav. dj., I., str. 185.

19 Cod. dipl., V., str. 76, 342.

20 Daniele Farlati - Jaсовo Coleto, "Ecclesiae ragusinae historia", u: Illyricum sacrum, VI. (dalje: D. Farlati, nav. dj., VI.), Venetiis, 1800., str. 293.

21 Augustinus Theiner, Vetera monumenta Slavorum meridionalim historiam illustrantia, I., Rim, 1863., str. 93 (dalje: VMSM); Cod. dipl., VI., str. 177-178.

22 K. JiREČEK, nav. dj., I., str. 186.

23 K. JirečEK, nav. dj., I., str. 181.

24 Pripisuju joj gradnju katoličke crkve u Orahu. Ljubo Sparavalo, "Srednjovjekovna groblja, crkvine i crkve na području Šume trebinjske", u: Tribunia, 5, Trebinje, 1979., str. 80-81; Đ. Tošıć, Trebinjska oblast, str. 21. 
mu uredila svoj dvor. ${ }^{25}$ Da je oživjela i biskupiju u Trebinju možemo zaključiti iz pisma pape Martina IV. (1281.1285.) dubrovačkom nadbiskupu Bonaventuri 1284 . godine u kome papa piše kako mu je do ušiju doprlo da "trebinjska i stonska katedralne crkve" već toliko vremena nemaju pastire pa piše da ih, prema svojoj uviđavnosti, popuni. Papa Martin je uskoro umro pa je nadbiskup 1286. godine upitao njegova nasljednika Honorija IV. (1285.-1287.) kako postupiti, a on mu je odobrio da izvrši naredbu pape Martina. ${ }^{26}$ Iz ovih se pisama vidi da do pape nije došla vijest preko nadbiskupa nego s druge strane. A budući da se kraljica Jelena dopisivala s papama, ${ }^{27}$ ne treba dvojiti da je ona tražila popunjavanje spomenutih biskupija. Nadbiskup Bonaventura je jedva dočekao ispuniti papin nalog zbog nedostatka sufragana. Ubrzo se u više dokumenata spominje stonski biskup Petar. ${ }^{28}$ Nemamo, na žalost, izravne potvrde da je nadbiskup posvetio i trebinjskoga biskupa, ali da je biskupija doista popunjena, doznajemo iz pisma pape Ivana XXII. (1316.-1334.) iz 1325. godine kojim naređuje da palij dubrovačkom nadbiskupu Tomi predaju biskupi kotorski i trebinjski. ${ }^{29}$

\section{Mrkan - sjedište trebinjskoga biskupa}

Pred Cavtatom je nekoliko manjih otoka: Mrkan, Supetar i Bobara. ${ }^{30}$ Mrkan je otočić (školj). Površina mu je $0,197 \mathrm{~km}^{2}$, dužina obale $3,26 \mathrm{~km}$, a najviši vrh $65 \mathrm{~m}$ nad morem. Uz njega je i mala hrid zvana Mrkanac. Bio je posjed plemićke obitelji Theophilis (Tefla). ${ }^{31}$ Otočić Supetar ima nisko položenu obalu, najviša mu je točka samo $8 \mathrm{~m}$ nad morem. Otočić Bobara ima površinu $0,064 \mathrm{~km}^{2}$, dužinu obale $1,25 \mathrm{~km}$. Najviši vrh je 45 metara. Otočići su naziv po sv. Marku, sv. Petru i sv. Barbari morali dobiti prije dolaska benediktinaca. Vjerojatno su im ga dali pustinjaci koji su, kako piše sv. Jeronim, ispunili "samoću dalmatinskih otoka". ${ }^{32}$ Benedik-

25 DAD, Lam. de fori, X., f. 326; Vladimir Ćorović, "Prošlost Hercegovine", u: Glasnik Jugoslovenskog profesorskog društva, juli - august, 1937., str. 15; Isti, Historija Bosne, I., Beograd, 1940., str. 231-232; Dominik Mandić, Bosna i Hercegovina, I., Chicago, 1960., str. 329; Đ. Tošı́́, Trebinjska oblast, str. 35, 80, 90, bilj. 17, 18.

26 A. Theiner, VMSM, I., str. 100; Cod. dipl., VI., str. 551. (U svesku III., str. 142 pismo je bilo pogrješno pripisano papi Honoriju III.).

27 K. Jireček, nav. dj., I., str. 181 i II., str. 76-77, 265; Dragomir Maritch, Papstbriefe an serbische Fiirsten in Mittelalter, Sremski Karlovci, 1933.

28 Cod. dipl., VII., str. 303 i VIII., str. 253, 580; D. Farlati, nav. dj., VI., str. 328.

29 D. FARLATI, nav. dj., VI., str. 125; PANDŽIĆ naprotiv papin nalog stavlja, prema Vatikanskom arhivu, u 1327. godinu. BAsılıus PANDŽıć, "De dioecesi tribuniensi et mercanensi", u: Studia Antoniana, 12, Romae, 1959., str. 85, bilj. 7.

30 Postojala je i hrid Superka koja je nestala u eksploataciji kamena za gradnju kuća u Cavtatu.

31 D. Farlati, nav. dj., VI., str. 294.

32 Jacques-Paul Migne, Patrologiae cursus completus, series latina, Parisiis, 1844.-1855., Vol. XXII., str. 517, 547, 594, 965; Josip Buturac, "Povijesni pregled redovništva u Hrvatskoj", u: Croatia Sacra, 20-21, Zagreb, 1943., str. 132. Tradicija kaže da je samostan sv. Petra sagradio sv. Jeronim! Ivan Ostojić, Benediktinci u Hrvatskoj, II., Split, 1964., 
tinci su na Mrkanu imali opatiju, na Supetru priorat ili eremitažu, dok na Bobari vjerojatno nije bila neka monaška nastamba. ${ }^{33}$

\section{1. "Episcopus Mercanae"}

Crkvene su odredbe strogo propisivale u kakvim se naseljima smiju a u kakvim ne smiju uspostavljati biskupije kako ne bi devalvirao ugled biskupske časti, ${ }^{34}$ pa otočić Mrkan nikad nije imao uvjeta da se na njemu uspostavi biskupija. ${ }^{35}$ Ipak prve spomene "biskupa Mrkana" susrećemo 1322. i 1323. godine, kada dubrovačko Malo vijeće odlučuje, kao zavjet da bi Bog čuvao Dubrovnik od zala, podijeliti milostinju od dva perpera "biskupu Mrkana". ${ }^{36}$ Biskup Mrkana se spominje i u testamentu Gervazija Junija Bunića 8. veljače 1325., u testamentu Perine, žene Ostojine 28. lipnja iste godine... ${ }^{37}$ Kako trebinjski biskup Nikola u testamentu iz 1326. godine piše da je "ep(isco)p(us) Tribunii atquae Mercane" doznajemo da je taj biskup Mrkana zapravo prognani trebinjski biskup. ${ }^{38}$ Zbog stvarne opasnosti od srpske države, biskupa se u Dubrovniku uporno ne zove trebinjskim nego samo mrkanskim sve do kraja srpske vladavine! Tek kad je ta opasnost minula, Veliko vijeće, prigodom darivanja školja Molonta 28. srpnja 1423. kaže da ga dariva "episcopatui Mercanae, scilicet(!) tribuniensi". 39

\subsection{Vrijeme progona trebinj- skoga biskupa na Mrkan}

O vremenu i razlogu progona biskupa iz Trebinja nemamo vijesti u izvorima. Vremenski se okvir ipak može dosegnuti na temelju podataka o benediktinskom samostanu na Mrkanu i na temelju prilika u srpskoj državi.

Vijesti o benediktinskom samostanu na Mrkanu počinju od 1218. godine i sežu do kraja XIII. stojeća. ${ }^{40}$ Posljednji

str. 470; Serafin Razzi, La storia di Ragusa, izdanje Dubrovnik, 1903., str. 220, bilj. pod tekstom.

33 I. Ostojić, nav. dj., I., str. 73 i II., str. 465-470.

34 Odredaba se strogo držala i crkva u Dalmaciji. Nada Klaić, Historia salonitana maior, Beograd, 1967., str. 82 (615r).

35 Zato u nekim edicijama čitamo da je Mrkan grad! "Mercana o Merca fu già città nell'isola del suo nome, in cui dopo il X secolo fu erreta una sede vescovile." GaEtano Moroni, Dizionario di erudizione storico-ecclesiastica da s. Pietro sino al nostri giorni, Vol. XLII., Venezia, 1847., str. 232-233.

36 Monumenta ragusina, Libri reformationum, I., u: Monumenta spectantia historiam Slavorum meridionalium, X., Zagreb, 1879., str. 73, 102.

37 D. FARLATI, nav. dj., VI., str. 293.

38 DAD, Sig. 12. ser. I, No. 2, f. 56; Marijan Sivrić, "Oporuke biskupa trebinjskomrkanske biskupije od 14. do 18. stoljeća", u: Hercegovina, 24, Mostar, 2010., str. 80; B. PAndžıć, De dioecesi, str. 17, osobito bilj. 4. Zabunom je godina 1326. zapisana kao 1236.

39 "Prima pars est ob reverentiam omnipotentis Dei de donando episcopatui Marchane silicet Tribuniensis scolium de Malonto..." DAD, Odluke Velikog vijeća, 28. srpnja 1423.

40 Josip Lučić (prir.), Spisi dubrovačke kancelarije - Zapisi notara Tomazina de Savere 12821284, u: Monumenta Ragusina, knjiga II., Zagreb, 1984., str. 297, 327, 330, 374, 379 
poznati opat Mato Ranjina Grubišin spominje se 1294 ., a posljednji poznati monah "frater Petrus de Mercana" preselio se na Lokrum gdje se spominje 1296. godine.$^{41}$ Prema tradiciji samostan je opustio od kuge. ${ }^{42}$

Nije vjerojatno da se progon trebinjskoga biskupa zbio za života obnoviteljice biskupije, kraljice majke Jelene, koja je sve do 1308. upravljala trebinjskim krajem ${ }^{43} \mathrm{i}$ umrla 1314 ., a vjerojatno ni do smrti kralja Dragutina 1316. godine. Kralj Stefan Uroš II. Milutin (1282.-1321.) od početka XIV. st. odvaja se od bratove politike, ${ }^{44}$ iako se četiri puta i tijekom njegove vladavine pregovaralo o sjedinjenju Srbije s Katoličkom crkvom (1291., 1303., 1306. i 1308.). ${ }^{45}$ Pregovori s papom Benediktom XI. (1303.-1304.) pružali su nadu u uspjeh, a 1308. papi Klementu V. (1305.-1314.) Milutin je obećao da će pristupiti Katoličkoj crkvi. ${ }^{46}$ Ipak se on u svemu oslanja na Pravoslavnu crkvu, gradeći joj brojne crkve i manastire, ${ }^{47}$ zbog čega ga ona naziva "svetim kraljem". Vjerojatno je taj prisni odnos s Pravoslavnom crkvom doprinio sve lošijim odnosom prema katolicima. Počinju se sve češće javljati pritužbe na progone katolika. Još se 1308. godine jedan zapadni putopisac u opisu istočne Europe potužio: "U ovom primorskom kraju stanovnici su čisti katolici, jednako kao Latini. Drugi pak ovoga kraljevstva i kralj nevjerni su raskolnici i zbog toga jako progone katolike i vrlo često razaraju i nište crkve Latina, napadaju crkvene dostojanstvenike, robe ih i mnoga neopisiva zla čine, pa su zbog toga navedene crkve siromašne." ${ }^{48} S$ vladavinom kralja Milutina počinje opasnije razdoblje od neprijateljstava u vrijeme kralja Uroša I. polovicom XIII. stoljeća. ${ }^{49}$ Papa Ivan XXII. kaže za njega da je u svemu neprijatelj kršćanske vjere. ${ }^{50}$ Milutin je nakon smrti kralja Dragutina 1316. godine zaposjeo njegove krajeve i bacio mu sina nasljednika Vladislava u

(dalje: J. Lučić, Monumenta Ragusina). Opat Andrija spominje se 1285. godine; Istı: Monumenta Ragusina, III., Zagreb, 1988., str. 82; Cod. dipl., IV., str. 561.

41 I. Ostojıć, nav. dj., II., str. 465 s bilješkama.

42 Giacomo Luccari, Copioso ristretto degli annali di Ragusa, Venezia, 1674., str. 101; I. Ostojić, nav. dj., II., str. 465.

43 Đ. Tošić, Trebinjska oblast, str. 80, 84.

44 Minailo Dinić, "Odnos između kraljeva Dragutina i Milutina", u: Zbornik radova Vizantološkog instituta, XLIV., knj. 3, Beograd, 1955., str. 49-82.

45 Đоко SlijepčEvić, Istorija Srpske pravoslavne crkve, I., Beograd, 2002., str. 137.

46 K. JiREČEK, nav. dj., I., str. 197, osobito bilješke ispod teksta.

47 K. Jireček, nav. dj., I., str. 202.

48 Olgierd Górka, Anonvmi descriptio Europae Orientalis... anno 1308, Krakov, 1916. str. 30s. (prema: D. Mandić, Bosna i Hercegovina, III., Etnička povijest Bosne i Hercegovine, reprint-izdanje, Mostar, 1982., str. 535).

49 Radoslav Grujić, Srpska Pravoslavna Crkva, Beograd, 1921., str. 23, 36; D. FarlaTI, nav. dj., VII., str. 63-64; Ivan Marković, Dukljansko-barska metropolija, Zagreb, 1902., str. $111-112 \mathrm{i}$ dr.

50 Prema: V. Ćorović, Istorija Srba, I., str. 178. 
tamnicu. ${ }^{51}$ Kako je počeo progoniti i prekrštavati katolike, papa je pokrenuo križarski rat protiv "nevjernoga raškog kralja". ${ }^{52}$ Ocjenjuju ga da je bio "velik kao vladar, ali rđav kao čovek". ${ }^{33}$ Znatno je na njega utjecalo i to što je s Dubrovnikom umalo trajno bio u lošim odnosima. Osobito je žestok rat bjesnio 1317.-1318. kada su Dubrovčani u strahu porušili franjevački samostan na Pilama. ${ }^{54}$ Ovaj rat je krajnji termin progona biskupa i njegova nastanjenja na Mrkanu.

\subsection{Posjedi mrkanskoga biskupa}

Samostanska zgrada na Mrkanu imala je kulu i dvije crkve: crkvu sv. Marije (Navještenja ili Gospe Snježne) po kojoj se samostan uglavnom zvao, te crkvu sv. Mihaela po kojoj se npr. 1252. godine ${ }^{55}$ samostan zove samostanom sv. Mihaela. Biskup je vjerojatno dobio sve bivše benediktinske posjede. Povremeno se (kao i u vremenima prije uz opata) kaže da se za samostanske posjede brinu i baštinici (haeredes, haereditarii). Vijeće umoljenih traži od nadbiskupa da imenuje prokuratora "duos in episcopatu
Margane" da se očuva samostanska imovina. Izabrana su dva klerika i dva laika. Među samostanima "koji sada nemaju rektora" navodi se 1327. godine i "monasterium Mergane". ${ }^{6}$ Mogli bismo zaključiti da je to učinjeno poslije smrti biskupa Nikole 1326. godine. ${ }^{57}$ Samostan se spominje 1347., 1349. pa čak i 1352. godine. ${ }^{58}$ Kao "prebendato" mrkanskoga područja 1360 . godine spominje se Marin de Saraca. ${ }^{59}$ Ovi podatci mogli bi se tumačiti da je u vrijeme upražnjene trebinjske (mrkanske) biskupske stolice brigu za samostan preuzimao dubrovački nadbiskup, kao npr. spomenute 1349 . godine, ${ }^{60}$ što bi mu kao metropoliti i bila dužnost.

Trebinjski je biskup, osim Mrkana, dobio i benediktinsku nastambu sv. Petra na Supetru. Spominje se u testamentu iz 1234. godine, pa više puta kroz XIII. stoljeće pod imenom sv. Petar "in Medio Mari", "de Medio Mari", "de Dimidio Mari" ili "Sanctus Petrus in Pelago". U jednom testamentu iz 1284. godine nastamba se zove samostanom. Obnovljen je 1295. godine. Biskup je na njemu imao ovlast vršiti

51 K. JiReČEK, nav. dj., I., str. 199.

52 Augustinus Theiner, Vetera monumenta historiam Hungariam sacram illustrantia (dalje: A. Theiner, $V M H H$ ), Rim, 1859., I., str. 830-831; K. JiReČEK. nav. dj., I., str. 201; Đ. Tošić, Trebinjska oblast, str. 84.

53 V. Ćorović, Istorija Srba, I., str. 165.

54 K. JIREČEK, nav. dj., I., str. 199-200; V. ĆOROvić, Istorija Srba, I., str. 177.

55 Cod. dipl., IV., str. 561; I. OsтoJı́́, nav. dj., I., str. 196, 241 i II., str. 467.

56 Monumenta Ragusina, V., str. 245-247; I. Оsтојı́́, nav. dj., II., str. 466.

57 Josip Sopta - Bernardin ŠKunca (prir.), Nekrologij Provincije sv. Jeronima u Dalmaciji i Istri, Dubrovnik, 2006., str. 144; D. Farlati, nav. dj., VI., str. 294; B. Pandžić, naprotiv kaže da mu Nekrologij godinu smrti bilježi 1333., De dioecesi, str. 85, bilj. 7.

58 Cod. dipl., XII., str. 86; I. Ostojıć, nav. dj., II., str. 467.

59 Monumenta ragusina, II., str. 290.

60 D. Farlati, nav. dj., VI., str. 296. 
sve biskupske čine i nitko ga u tome nije ometao. ${ }^{61}$ Cavtaćani su kamen samostana odvezli kao građevinski materijal, a crkva se duže vremena održala. Biskup je dobio i otočić Bobaru koji je također pripadao mrkanskom samostanu. ${ }^{62}$ Spomenuta opatija i nastambe imali su neke posjede (vinograde) u Župi pa i drugdje. ${ }^{63}$ Župu s okolicom (Astarea) susjedni su vladari često pustošili, ali je poslije sklapanja mira ostajala u posjedu Dubrovnika. Jedino je kralj Milutin 1302. godine zauzeo Cavtat koji je vraćen Republici tek 1426. godine. ${ }^{64}$

Republika je 1377. godine mrkanski samostan s otocima odredila za karantenu. ${ }^{65}$ Podignute su drvene barake okružene zidom. Trgovci iz okuženih krajeva tu su boravili 30 (kasnije 15) dana. Biskup je dobio u naknadu kuću u samom gradu i još neke zemlje na vodovodu (Konalu) i u Župi. Domalo je karantena premještena na otoke sv. Andriju, Lokrum i Mljet, dok nije 1466. godine počela izgradnja Lazareta, neposredno uza sam grad. ${ }^{66}$

\subsection{Prilike u Biskupiji nakon progona trebinjskoga biskupa}

Kad je kralj Milutin umro 1321. godine, izbio je sukob za prijestolje u kome je odnio pobjedu njegov sin Stefan Uroš III. Dečanski (1321.-1331.). Njega je naslijedio Stefan Dušan kao kralj 1331.-1346., a onda do 1355. kao car. U odnosu prema Katoličkoj crkvi oba su išli stopama kralja Milutina. Uskoro nakon Dušanova nastupa izbio je ustanak u katoličkom primorju pa je protiv njega pripreman i križarski rat. ${ }^{67}$ Čak četiri članka njegova zakonika ${ }^{68}$ donose oštre odredbe protiv "latinske jeresi". Kad je 1346. godine proglašen carem ponadao se da će biti postavljen na čelo kršćanske vojske u borbi protiv Turaka pa je stupio u kontakt $s$ papom. Iz pisama pape Klementa VI. (1342.-1352.) njemu, hrvatsko-ugarskom kralju i bosanskom banu ${ }^{69}$ na svjetlo izlazi da su

61 D. Farlati, nav. dj., VI., str. 294, 296; I. Ostojić, nav. dj., II., str. 469-470, s popratnim bilješkama.

62 I. Ostojıć, nav. dj., II., str. 465-470.

63 "... terra ecclesie mercane" spominje se 1297. J. Lučić, Monumenta ragusina, III., str. 275; Marijan Vujnović, "Dobra i posjedi trebinjsko-mrkanjske biskupije", u: Vrhbosna, LI, br. 4-5, Sarajevo, 1937., str. 103-107.

64 Josıp Lučić, "Iz prošlosti Župe dubrovačke", u: Zbornik Župe Dubrovačke, Dubrovnik, 1985., str. 93; Isti, Prošlost dubrovačke Astareje (Župe, Šumeta, Rijeka, Zatona, Gruža i okolice grada do 1366), Dubrovnik, 1970.

65 I. Ostojıć, nav. dj., II., str. 468. Usp. odluku Maloga vijeća od 17. lipnja 1390. Nella LonZa - ZdRAVko Śundrica, Odluke dubrovačkih vijeća 1390-1392, Zagreb - Dubrovnik, 2005., str. 80.

66 Branko Kojić - Radojica Barbalić, Ilustrirana povijest jadranskog pomorstva, Zagreb, 1975., str. 59; I. Ostojıć, nav. dj., II., str. 468.

67 K. JIREČEK, nav. dj., I., str. 213.

68 Nikola Radojčić, Zakonik cara Stefana Dušana 1349. i 1354., Beograd, 1960., str. 44-45, 90-91; Sime Ljubić, Listine o odnošajih između južnog Slavenstva i mletačke Republike, III., Zagreb, 1872., str. 186; K. JirEČEK, nav. dj., I., str. 233.

69 Cod. dipl., XI., str. 179-180, 264-267; K. JIREČEK, nav. dj., I., str. 265-266 i II., str. 78. 
u proteklom vremenu srpski vladari katolike koje nisu uspjeli uklopiti u srpsko pravoslavlje podvrgavali kotorskom biskupu. Jurisdikcija kotorskih biskupa proširila se na katolike sve do Dunava. Bilo je to kompromisno rješenje u sukobu (nad)biskupa Dubrovnika i Bara za metropolitansku vlast ${ }^{70}$ nad biskupijama Gornje Dalmacije koji je trajao (s kraćim zatišjima) već od uspostave Barske nadbiskupije 1089. godine. Upravo je ta borba bila često povod ratova srpskih vladara $s$ Dubrovnikom pa posredno i uzrok nevolja Trebinjske biskupije. Kotorski biskup, da izmakne posljedice toga sukobljavanja, podvrgao se još 1178. metropoliti u talijanskom Bariju i pod njegovom vlašću ostao sve do 1828 . godine. ${ }^{71} \mathrm{Na}$ vrijeme uprave kotorskih biskupa uspomena je širenja štovanja sv. Tripuna što svjedoče crkve na Uskoplju ${ }^{72}$ i u Cavtatu. Papa Klement VI. u pismima Dušanu iz 1345. godine svjedoči da kotorskom biskupu kao dijecezanskom pripadaju mnoge crkve i na području Trebinjske biskupije: "sancte Marie de Resson, sancti Petri de Campo... sancti Triphonis de Zeptat, sancti Martini de Canal... necnon de Molonat". Sljedeće godine papa piše da je kotorski biskup "tamquam diocesanus" upravljao preko svojih vikara i službenika Trebinjem, Konavlima, Dračevicama, Risnom, Lastvom..., dakle čitavom povijesnom Trebinjskom biskupijom. Navodi se čak i "Chelminia" (Humska zemlja) i katolici sve do Save i Beograda. Papa piše i bosanskom banu Stjepanu da je Humska zemlja pod jurisdikcijom kotorskoga biskupa. ${ }^{73} \mathrm{~A}$ caru Dušanu piše da su neki njegovi prethodnici navedene crkve i krajeve oteli kotorskom biskupu te da ih i on drži. Pritisci srpskih vladara i na kotorske biskupe poznati su i iz drugih izvora. ${ }^{74}$ Od pregovora s papom Dušan je ubrzo odustao te se već 1350. godine javljaju vijesti da je silio katolike da prijeđu na pravoslavlje i da se ponovno krste. Međutim, opet je 1354. godine pisao papi Inocentu VI. (1352.-1362.) kako je zabranio da se katolici ponovo krštavaju te da je naredio da se svrgnuti katolički biskupi i svećenici mogu vratiti i da im se vrate oteti samostani i crkve. I ovi su pregovori ipak bili kratkoročni. Već sljedeće godine papini su poslanici naišli na hladan doček. ${ }^{75}$

Dok se u Dubrovniku iz političkih razloga desetljećima ne spominje

70 I. Marković, Dukljansko-barska metropolija; I. Puljıć, "Uspostava dubrovačke metropolije", u: Tisuću godina dubrovačke (nad)biskupije, Dubrovnik, 2001. Usp. i S. STANojević, nav. dj., zatim djela: Ivan Jovović, Iz prošlosti dukljansko barske nadbiskupije, Bar, 2004.; EdUARD PeričIĆ, Sclavorum regnum Grgura barskog - Ljetopis Popa Dukljanina, Zagreb, 1991.

71 K. Draganović, Opći šematizam Katoličke crkve u Jugoslaviji, Sarajevo, 1939., str. 229 i Opći šematizam Katoličke Crkve u Jugoslaviji, Zagreb, 1975., str. 276.

72 Lj. Sparavalo, nav. dj., str. 67-69; Đ. Tošı́, Trebinjska oblast, str. 23.

73 A. Theiner, VMSM, I., str. 216; Isti, VMHH, I., str. 701; Cod. dipl., XI., str. 265.

74 Cod. dipl., IX., str. 517-525; K. JirečEK, nav. dj., I., str. 255-266 i II., str. 78; I. Puljić, Tisuću godina, str. 71.

75 K. Jiré̌EK, nav. dj., I., str. 233-235. 
trebinjski biskup, u rimskim dokumentima u proteklom razdoblju susrećemo nasljednike biskupa Nikole. Papa Klement VI., premještajući 1344. godine biskupa Bonifacija na šibensku biskupsku stolicu, piše za njega: "eidem Tribuniensi ecclesiae laudabiliter prefuisti", ${ }^{76}$ što je vjerojatno samo uobičajena formulacija. Spominje se i trebinjski biskup Ivan de Mobili (od 1345.). Papa Klement VI. o upravljanju biskupijom govori i 1349. godine prigodom imenovanja biskupa Ivana de Rupella (1349.1351.). U rimskim dokumentima slijede biskupi Matia de Altamuta (de Alta Muta, Altamura, odnosno Hohenmaut, od 1355.) i Nikola de Paden (od 1371.). ${ }^{77}$ Neki noviji istraživači tvrde da biskup Crafto (1350.1355.) nije bio makarski nego mrkanski biskup, ${ }^{78}$ a možda i neki drugi iz popisa zbog sličnosti naziva biskupija što se ne može kategorički ni tvrditi ni nijekati jer se u dubrovačkim aktima biskupi Mrkana spominju doista samo usputno, kao npr. 1361. godine kada Malo vijeće dodjeljuje "fratri Desse episcopo Mercane" pet perpera za korizmene propovijedi. ${ }^{79}$ Možda je Deša (imao je ime i Ulia) i onaj mrkanski biskup koji se spominje 1362., 1366. ... Abdicirao je i otišao u rodni
Trogir gdje je po svoj prilici 1370. godine umro. U presudi pape Urbana VI. iz 1386./1387. u sporu oko njegove ostavštine u Trogiru papa ga zove "episcopus Marchanensis"80 što je prvi spomen mrkanskoga biskupa u papinskim dokumentima.

\section{Ujedinjenje trebinjskoga i mrkanskoga naslova}

Dušanov sin i nasljednik car Stefan Uroš (1455.-1471.) također je izazvao protiv sebe pokretanje križarskoga rata. ${ }^{81} \mathrm{Za}$ vrijeme njegove vladavine država brzim koracima propada. $\mathrm{Na}$ trebinjskom području ojačao je knez Vojislav Vojnović. Poslije njegove smrti njegovu je udovicu 1368. godine protjerao Nikola Altomanović. On je svojom okrutnošću izazvao protiv sebe savez svih susjeda (bana Tvrtka, kneza Lazara, zetske braće Balšića i hrvatskougarskoga kralja Ljudevita) koji 1373. godine podijeliše njegove posjede. Trebinjsko područje dobili su Balšići.

\subsection{U susret slobodi}

Dolaskom trebinjskoga područja pod vlast zetske braće Balšića prilike su se promijenile. Posredstvom svačkog biskupa Balšići su često komuni-

76 A. Theiner, VMSM, I., str. 210-211; Cod. dipl., XI., str. 112-113, 170-171; D. Farlati, nav. dj., VI., str. 204; B. PAnDžIĆ, De dioecesi, str. 85.

77 D. Farlati, nav. dj., VI., str. 294-295; B. Pandžić, De dioecesi, str. 86.

78 Marijan Žugaj, "Hrvatska biskupija od 1352. do 1358. godine", u: Croatica christiana periodica, 17, Zagreb, 1986., str. 102.

79 Deša (Desa) se zvao i Ulija. Giovanni Lucio, Memorie istoriche di Tragurio ora detto Trau, Venecija, 1674., str. 331; D. FARlati, nav. dj., VI., str. 295-296; Cod. dipl., XVII., str. 12.

80 D. Farlati, nav. dj., VI., str. 295.

81 Š. LjubiĆ, nav. dj., III., str. 327; K. JireČEK, nav. dj., I., str. 239. 
cirali $s$ papom ${ }^{82}$ i vratili se Katoličkoj crkvi. Osobito je važno to što su bili u prijateljskim odnosima $s$ Dubrovnikom, ${ }^{83}$ ali i to što su bili u sukobu s Kotorom! ${ }^{84}$ Dubrovčani su očito odlučili iskoristiti prijateljstvo s Balšićima s obzirom na Trebinjsku biskupiju dok su im među legatima poslali i mrkanskoga biskupa. ${ }^{85} \mathrm{Mr}-$ kanskoga biskupa Franju, koji se spominje 1370., zovu 1373. trebinjskim biskupom, a i on se sam 1374. godine predstavlja: "Dei gratia episcopus Tribuniensis et Merchantium." 86

\subsection{Osvrt na posljedice srpske vladavine}

Premalo je izvorne građe na temelju koje bismo mogli procijeniti koliko su štete nanijeli progoni katolika na području Trebinjske biskupije u vrijeme srpske vladavine. Neke nas vijesti naprotiv ostavljaju u nedoumici jer je teško povući jasnu crtu između katoličkoga svećenstva slavenske službe
Božje i službenika Pravoslavne crkve. Zašto bi srpski sinodici proklinjali uz heretike i "popove" ako je riječ o pravoslavnim popovima? Uz druge heretike proklinju se i "pop Tvrdoš... pop Braten" te "pop Drug". ${ }^{87}$ Ako već nisu pravoslavni, očito su mogli biti katolički glagoljaši. Zapadna ćirilica dominantno je pismo na stećcima i u praktičnoj uporabi i na trebinjskom području, čak i u natpisu koji spominje popa Bokčina u Trebinju! ${ }^{88}$ Začuđujuće je velik broj porušenih crkava iz srednjega vijeka ${ }^{89}$ za koje se danas ne može utvrditi konfesionalna pripadnost, ali da su bile pravoslavne ne bi bilo razloga za njihovo rušenje. Brojne su vijesti o preotimanju starih katoličkih crkava sve do kraja turske vladavine.

Zanimljivo je da se na ovim prostorima nije zatrlo ni hrvatsko ime. Valjda je Dukljanin bolje znao kako mu se domovina zove kad je zove Crvenom Hrvatskom ${ }^{90}$ od autora koji to nakon

82 A. Theiner, VMSM, I., str. 261-264; D. Farlati, nav. dj., VIII., str. 279-280; K. JireČEK, nav. dj., I., str. 243, 248.

83 V. Foretić, Povijest Dubrovnika do 1808., I., Zagreb, 1980., str. 217-226; K. Jireček, nav. dj., I., str. 243.

84 Papa Urban V. posredovao je za Kotor kod Balšića: A. Theiner, VMHH, II., str. 86.

85 B. PAndžIĆ, De dioecesi, str. 87, bilj. 2.

86 Cod. dipl., XIV., str. 64 i XV., str. 64, 415; D. Farlati, nav. dj., VI., str. 295; B. PanDŽIĆ, De dioecesi, str. 20, 87. Franjo je vjerojatno trebinjski biskup koga je papa imenovao 1378. godine posrednikom u sporu između stonsko-korčulanskoga biskupa i Dubrovnika. Farlati misli da je Deša-Ulija. "Damianus nepos episcopi mercanensis" spominje se 1379. Monumenta ragusina, IV., str. 51, 230.

87 Dominiк Mandić, Bogumilska crkva bosanskih krstjana - Bosna i Hercegovina, izdanje, Chicago - Roma - Zürich, 1979., str. 50; Franjo Sanjex, Bosansko-humski krstjani u povijesnim vrelima (13.-15. st.), Zagreb, 2003., str. 312.

88 Marko Vego, "Novi i revidirani natpisi iz Hercegovine", u: Glasnik Zemaljskog muzeja (dalje: GZM), Sarajevo, 1964., str. 178-179; Đ. Tošić, Trebinjska oblast, str. 35.

89 Đ. Tošıć, Trebinjska oblast, str. 12-42, osobito 47-48; LJ. SParavalo, nav. dj., str. 53-137.

90 Usp. F. Šıšıć, Letopis, (poglavlje IX.), str. 306; V. Mošın, Ljetopis, str. 54 . O Crvenoj Hrvatskoj napisane su brojne rasprave, usp. Savo Marković Śtedimlija, Crvena Hrvatska, Zagreb, 1937. i Split, 1991; Dominik Mandić, Crvena Hrvatska u svjetlu povijesnih izvo- 
više od tisuću godina niječu! Slijede ga i dubrovački kroničari (Ranjina, Orbini, Lukarević, Crijević, Rastić). Znakovita je i česta uporaba osobnoga imena Hrvat i Hrvatin na ovim prostorima, ${ }^{91}$ čak i u početku turske vladavine. ${ }^{92}$

\section{Prilike u biskupiji u sklopu bosanske države}

Ban Tvrtko se 1377. godine okrunio za kralja. Izjasnio se kao "biljka Katoličke crkve". ${ }^{3} \mathrm{U}$ ovo je vrijeme u prijateljskim odnosima s Dubrovni- kom. Kancelara kancelarije stonskoga kneza, svećenika don Ratka Priboju, uzeo je od 1375. za dvorskoga kapelana te ga domalo imenovao svojim protovestijarom. ${ }^{94}$ Ratko je na dvoru igrao veliku ulogu kao jedan od rijetkih učenih ljudi u kraljevu okruženju pa mu se ime spominje u brojnim dokumentima. ${ }^{95}$ Malo je vijeće iz zahvalnosti 1378. godine uputilo molbu nadbiskupu da ga kao kanonika uvrsti u kaptol. Kao protovestijar posljednji se put spominje 1382. godine kad se vjerojatno vratio u Dubrovnik. ${ }^{96}$

ra, Chicago - Rim, 1973.; Nikola Zvonimir Bjelovučić, Crvena Hrvatska i Dubrovnik, Zagreb, 1929. i dr.

91 Godine 1319. spominje se Hrvatin s Rudina: Minailo Dinić, Humsko-trebinjska vlastela, Beograd, 1967., str. 79. Godine 1301. spominje se "Croatinus de Trebigna" pa opet 1319., 1325. i 1330. kao i ugledni vlastelin Hrvatin i brat mu Vojin iz dubrovačkoga zaleđa: Vinko Foretić, "Smještaj Hrvata i Srba u srednjem vijeku s naročitim obzirom na Crvenu Hrvatsku", u: Dubrovnik, IV., Dubrovnik, 1969., str. 94-96 i bilj. 73; MariJan Sivrić, "Srednjovjekovna župa Dabar", u: Srednjovjekovne humske župe, Mostar, 1999., str. 210; Domagoj Vidović, "Razvoj hrvatskog sustava osobnih imena u istočnoj Hercegovini", u: IviCa Lučić (ur.), Hum i Hercegovina kroz povijest, I., Zagreb, 2011., osobito str. 813, 815. Godine 1381. spominje se Hrvatin Pivčević s područja Trebinja: V. Foretić, Smjesttaj Hrvata i Srba, str. 94-96; M. Dinić, Humsko trebinjska vlastela, str. 35-36. Za njega se 1383. godine kaže "Chervatinus Picheuich de Deber": M. SIVRIĆ, Srednjovjekovna żupa Dabar, str. 210. Godine 1395. spominju se Hrvatin Slavogostić, (Slavogostići su i "Vochaz" [njegov čovjek je Jurko] pa Novak i Dobrašić) kao i Hrvatin Tvrtković s Plane, DAD, Lam. de for., 8, fol. 141 i 9, fol. 112; M. Dinić, Humsko trebinjska vlastela, str. 8485. Godine 1397. spominje se Hrvatin Trkulić iz dubrovačkoga zaleđa: V. Foretić, nav. dj., str. 94-95. Godine 1445. spominje se župan Ratko Hrvatinović kao svjedok i Hrvatin Mrđenović. Usp. M. Dinić, Humsko trebinjska vlastela, str. 65, 85.

92 U Biogradu na području Nevesinja popis navodi Vukasa i Vukašina sinove Hrvatina, zatim Bogdana sina Hrvatova, u nahijama Samobor, Goražde i Popovo postojao je "timar kneza Hrvatina, Stjepana i Radonje" kao i posjed "Gornja Vrba" u "Dubštici". Ahmed S. Alıčıć (prir.), Poimenični popis sandžaka vilajeta Hercegovina, Sarajevo, 1985., str. 323, 334, 372, 446-447, 571-572.

93 D. Farlati, nav. dj., III., str. 334; Marko Perojević, u: Povijest Bosne i Hercegovine, knjiga I., Sarajevo, 1942.-1991., str. 345. (Služimo se Napretkovim reprint-izdanjem, Sarajevo, 1991. (dalje: Povijest BiH, I.); Đ. Tošıć, Trebinjska oblast, str. 87.

94 Monumenta ragusina, IV., str. 157, 161, 164-165, 172, 174, 244; Đuro TošIć, "Dubrovčanin prezviter Ratko, stonski kancelar, kapelan i protovestijar kralja Tvrtka I i trebinjsko-mrkanjski biskup", u: "Godišnjak" Društva istoričara Bosne i Hercegovine, god. XXVIII-XXX (1977.-1979.), Sarajevo, 1979., str. 39-58.

95 Đuro Tošıć, "Dubrovački prezviter Ratko", str. $42-50$ i brojni citati dubrovačkih dokumenata u bilješkama.

96 Đ. Tošić, "Dubrovački prezviter Ratko", str. 49. 


\subsection{Trebinjsko-mrkanski bisku- pi u vrijeme bosanske države}

Od početka 1383. godine Ratko, bivši protovestijar kralja Tvrtka, u dubrovačkim dokumentima zove se trebinjsko-mrkanskim biskupom. ${ }^{97}$ Kako je prema oporuci umro 1397. godine, ${ }^{98}$ biskupske se stolice očito odrekao više godina prije 1391., kada trebinjsko-mrkanski biskup Jakov Norvegius plaća neki dug svoga prethodnika biskupa Ivana, koji je vjerojatno naslijedio biskupa Ratka. $\mathrm{O}$ njemu nemamo drugih vijesti. Biskupa Jakova je 1416. naslijedio dominikanac Ivan Muzarić (Masdrach), po nekim autorima član ugledne trebinjske porodice, u rodbinskim vezama čak i sa Sandaljom Hranićem. ${ }^{99}$ Dubrovačko Veliko vijeće 28. srpnja 1423. odlučuje da se dade "episcopatui Mercanae, scilicet tribuniensi, scholium de Molonto". ${ }^{100}$ Time je senat stekao pravo imenovanja trebinjskih biskupa. Biskupa Muzarića je 1425. naslijedio Dominik Grancorve koji je vjerojatno umro 1435 . godine. Senat je imenovao biskupom nekoga Ivana.
Međutim, nadbiskup se tomu usprotivio pa je za novoga biskupa 1436. godine posvećen Mihael Natalis. ${ }^{101}$

O pastoralnom djelovanju biskupa u Trebinjskoj biskupiji nemamo skoro uopće vijesti. Teško ih je i očekivati jer se umalo sve vijesti u dubrovačkom arhivu odnose na političke i trgovačke odnose, na pljačke i sukobe... Pa i vijesti o biskupu najvišega ugleda, biskupu Ratku, odreda su usputne u određenim prigodama civilnoga karaktera. O njihovoj biskupskoj službi vijesti su također usputne i to o onome što su činili u Dubrovniku kad su zamjenjivali nadbiskupa kao delegati, prokuratori ili vikari. ${ }^{102}$

Kroničar Resti piše da su Dubrovčani u ratu s braćom Pavlovićima (1430.1433.) za njihov dio Konavala i neke druge predjele tražili od sultana da im preda Pavlovića posjede, argumentirajući to činjenicom što se još uvijek vide po Trebinju crkve i samostani koje su Dubrovčani gradili, te dodaju kako "le prime dignita prelatizie di quei loughi conservarsi a $\mathrm{Ra}$ gusa, come il vescovo di Trebigne". ${ }^{103}$

97 DAD, Diversa Canc., XXV., f. 171', 177', XXVI., f. 101, 136 i dalje, zatim Lettere di Lev. IV., f. 69; Đ. Tošić, "Dubrovački prezviter Ratko", str. 49, bilj. 57. Ponekad se i kasnije zove samo mrkanskim: 1385. "Dei gratia episcopus Mercanensis", a 1390. "Ratchus episcopus Merchanensis"... D. Farlati, nav. dj., VI., str. 296; N. LonZA - Z. Šundrica, nav. dj., str. 63, 73.

98 M. Sivrić, Oporuke, str. 80. Sivrić je ispravio Pandžićevo mišljenje da je umro oko 1393. godine.

99 D. Farlati, nav. dj., VI., str. 296; B. PandžIĆ, De dioecesi, str. 86, 88.

100 DAD, Odluke Velikog vijeća, 28. srpnja 1423.; D. Farlati, nav. dj., VI., str. 297; B. PANDžić, De dioecesi, str. 23, bilj. 3.

101 Biskup Dominik je biskupijom upravljao 1425.-1435. D. Farlati, nav. dj., VI., str. 297; B. PandžIĆ, De dioecesi, str. 88.

102 Đ. Tošıć, "Dubrovački prezviter Ratko", str. 51, bilj. 64, 65.

103 Speratus (Natko) Nodilo, "Chronica Ragusina", u: Monumenta spectantia historiam Slavorum Meridionalium, XXV., Zagreb, 1893., str. 249. Dubrovčani su i kralju Tvrtku ukazivali na to kako njihov prelat nosi naslov trebinjskoga biskupa! ĆIro TruHeLKa, 
Sa sigurnošću iz ove vijesti slijedi ipak samo to da je u vrijeme spomenutoga rata biskup boravio u Dubrovniku.

Vjerski život na području biskupije nije bio predmet zanimanja dubrovačkih notara. Ipak, znamo da se 1411. godine slavio sv. Martin u Mratinju ${ }^{104}$ kod Plužina. U sklopu crkve sv. Stjepana na Śćepan-Polju pod Sokolom ima prostorija zvana "misa". ${ }^{105} \mathrm{Bez}$ obzira gdje su biskupi duže ili kraće stanovali u vrijeme bosanske vladavine, nemamo drugoga objašnjenja tko bi upravljao vjernicima u biskupiji osim trebinjskih biskupa. Njihovo rezidiranje i na području biskupije potvrđuje kroničar Lukarević koji piše da se biskup Mihael povukao 1456. godine u Dubrovnik "raccomandata la dioecesi alli canonici di San Pietro di Cicevo et a Ivan conte di Popovo et di Trebigne". ${ }^{106}$ Biskupi su, dakle, imali rezidenciju i u drevnom benediktinskom samostanu sv. Petra u Polju gdje su imali i kaptol. ${ }^{107}$

Lukarićeva bilješka o Ivanu knezu (conte) Trebinja i Popova, kojemu biskup Mihael povjerava biskupiju, također je dragocjena jer je Popovo župa Humske zemlje, a ne Tribunije. U vrijeme srpske vladavine, kako smo vidjeli, i Humska se zemlja spominje u jurisdikciji kotorskoga biskupa. U vrijeme vladavine Šubića čitava Humska zemlja bila je u jurisdikciji duvanjskoga biskupa. ${ }^{108}$ Kod kroničara godine nisu tako pouzdane kao zemljopisno nazivlje i događanja. Farlati je Ivaniša poistovjetio s Ivanišem Pavlovićem. ${ }^{109}$ Napuštanje biskupije bi se onda moralo zbiti znatno prije, jer je Ivaniš 1450. umro, a osim toga, Pavloviće je herceg Stjepan istisnuo iz Trebinja još 1436. godine. ${ }^{110}$ Trebalo bi možda dublje proučiti i ulogu Ivaniša Vlatkovića u ratovanju na ovim prostorima.

Početci samostana sv. Petra u Polju, sudeći prema arheološkim nalazima, sežu u kasnu antiku. Veoma je dragocjena bilješka Anastazija, bibliotekara svete Rimske crkve, u Epitomama (Izvodu) Montekasinske kronike koja je prepisana prema naredbi pape Stjepana II. (752.-757.), gdje piše da je car Justinijan (527.-565.) darovao svom suvremeniku sv. Benediktu mnoga zemljišta, pa među onima u onodobnoj

"Konavoski rat 1430-1433", u: GZM, Sarajevo, 1917., str. 195; Đ. Tošrć, Trebinsjka oblast, str. 108.

104 Marko Vego, Iz istorije srednjovjekovne Bosne i Hercegovine, Sarajevo, 1980., str. 427.

105 Desanka Kovačević-Kojıć, Gradska naselja srednjovjekovne bosanske države, Sarajevo, 1978., str. 302 i literatura u bilj. 80.

106 G. Luccari, nav. dj., str. 101.

107 Prema tradiciji i kanonici su se povukli pred Turcima u Bobane gdje im se zameo trag. U neobjavljenim spisima don Marjana Vujnovića, župni arhiv u Trebinju.

108 Hvaranin Vitus de Ruschis zove se "episcopus Dumnensis et totius terre Cumnensis". D. Farlati, nav. dj., VI., str. 190; Ante ŠKegro, Na rubu opstanka. Duvanjska biskupija od utemeljenja do uključenja u bosanski apostolski vikarijat, Zagreb, 2002., str. 178-179.

109 D. Farlati, nav. dj., VI., str. 298.

110 V. Ćirković, Herceg Stefan Vukčić-Kosača i njegovo doba, Beograd, 1964., str. 120, bilj. 5. Ivaniš nema neke vlasti nego od 1441. Đ. Tošić, Trebinjska oblast, str. 115, 208. 
Dalmaciji Pontem Tiluri, Lausinium i Salluntum. ${ }^{111}$ Carevom politikom da unaprijedi carstvo u svakom pogledu benediktinci su dobivali posjede u poljima da, sukladno svom nepisanom geslu "moli i radi", njihove nastambe budu učilišta ne samo slova nego i uljudbe uopće. Lausinium arheolozi i povjesničari različito lociraju. Tabula Peutingeriana postaju Leusino smješta na cesti od Narone do Scodra u smjeru kroz unutrašnjost preko Nikšića prema postaji Sallunto, i to kao prvu postaju nakon raskrižja $A d$ Zizio, odakle drugi krak ceste vodi na jug prema Epidaurumu (Cavtatu). ${ }^{12} \mathrm{Na}$ istom putnom pravcu postaju Leusinio spominje i Itinerarium Antonini. ${ }^{113}$ Raskrižje (Ad) Zizio (Ad Dzidzio, Ad Zizio, Zidion) treba tražiti na području gdje je uvijek bilo prirodno križanje putova iz doline Neretve prema istoku i onih od mora prema unutrašnjosti, a to je šire područje Huma, Duži, Drijena... Brdo i selo Cicina sugeriraju na postaju Zizio(n). Prva postaja od ovoga križanja na ogranku prema unutrašnjosti bila je Leusino (Leusinio) i najlogičnije ju je locirati u užu trebinjsku okolicu.

Prostrana antička bazilika u dživarskom polju (pisci kažu u Čičevu, Crnču, riječ je o Bihovu, čiji je zaseok Crnač ${ }^{114}$ porušena je najvjerojatnije prvi put tijekom seobe naroda. Dubljim istraživanjima prepreka je novopodignuta pravoslavna crkva 1906. godine u središtu bazilike. U siromašnijim vremenima srednjega vijeka benediktinci je nisu mogli obnoviti pa su ostatke njezinih zidova adaptirali za samostan što se vidi po preziđivanjima. U neposrednoj blizini u sklopu samostanskoga kompleksa podigli su skromniju, znatno manju, srednjovjekovnu crkvu. ${ }^{115}$ Pučka tradicija ovu je manju crkvu sv. Petra pripisala sv. Pavlu, ne razlikujući da jednu i drugu dijele stoljeća! Samostan se stoljećima spominje kao samostan ili crkva svetoga Petra (Sancti Petri in Campo... de Campo... di Campo... di Tribigna... di Cicevo), a sv. Pavao se nikad ne spominje u povijesnim vrelima. ${ }^{116} \mathrm{Sa}$ mostan je bio mjesto ukopa vladara.

111 I. Ostojıć, nav. dj., I., str. 80; I. Puljić, Tisuću godina, str. 56.

112 Konrad Miller, Tabula Peuntigeriana, u: Itineraria romana, Stuttgart, 1916., IV., 468. prema: Nenad Cambi - Uroš Pasini, "Antički izvori o Naroni i Neretvi", u: Dolina rijeke Neretve od prethistorije do ranog srednjeg vijeka, Split, 1980., str. 288-289.

113 Gustav Parthey - Moritz Pinder, Itinerarium Antonini Augusti et Hierosolymitanum, Berlin, 1848., prema: N. CAMBI - U. PAssini, nav. dj., str. 289; Ivo Bojanovski, "Rimska cesta Narona Leusinium", u: Godišnjak, X., centar za balkanološka ispitivanja, knjiga 8, str. 168; E. PAšAlić, Antička naselja i komunikacije u Bosni i Hercegovini, Sarajevo, 1960., str. 62.

114 Đ. Tošıć. Trebinjska oblast, str. 69, 75, bilj. 48.

115 Đ. BAsLer, "Arheološki spomenici na području trebinjske biskupije", u: Tisuću godina trebinjske biskupije, str. 35. Isti, Kršćanska arheologija, Mostar, ${ }^{2} 1990 .$, str. 121.

116 Samostan nema sreće $s$ istraživačima, razlozi su uglavnom nepovijesni i neznanstveni. Prva površna istraživanja obavio je 1883. godine general Babić. Istraživanja Vladimira Ćorovića puno su obećavala (usp. Jugoslovenski istorijski ćasopis, I., Beograd, 1935., str. 750-751), a onda se sva dokumentacija tijekom Drugoga svjetskog rata "izgubila". Članak koga je objavio S. Delić ("Petrov manastir kod Trebinja", u: GZM, XXIV., Sarajevo, 1912., str. 275-282) samo je površni šturi prikaz o samostanu. Za srednjovjekovnu 
Dukljanin piše da je tu pokopan kralj Radoslav, ${ }^{117}$ a Orbini navodi osim Radoslava i velikoga župana Dešu. ${ }^{118} \mathrm{Sa}$ mostan je i kasnije igrao važnu ulogu. Tu se odvijaju i važni politički događaji, kao npr. 1401. godine pri rješavanju jedne zavjere. ${ }^{119}$

\subsection{Prisutnost bosansko-hum- skih "krstjana" na području Trebinjske biskupije ${ }^{120}$}

Nemanjin sin Vukan, kralj Duklje, optužio je papi 1199. godine bosanskoga bana Kulina i njegovu sestru, udovicu humskoga kneza Miroslava, da su preveli u herezu više od deset tisuća osoba. ${ }^{121} \mathrm{Ne}$ znamo da li se optužba odnosi i na trebinjsko područje. Kako su srpski vladari bili nesno- šljivi prema svim "hereticima", 122 (a u heretike su ubrajali ne samo "krstjane" nego nerijetko i katolike!), širenje "krstjana" na trebinjskom području u doba srpske vladavine teško je pretpostaviti. Međutim, iako su bosanski banovi i kraljevi ispovijedali katoličku vjeru, visoka ih bosanska vlastela uglavnom u tome nije slijedila. Po osvajanju trebinjskoga područja, najveći dio biskupije (Trebinje, Vrm, Bileća, Fatnica, pola Konavla...) dobili su sinovi ubijenoga velikaša $\mathrm{Pa}$ vla Radinovića, Petar i Radoslav, po kome su prozvani Pavlovići. Radoslavljevi sinovi Petar i Nikola priznavali su se sljedbenicima krstjana, jer otvoreno kažu da su se posavjetovali "s našimi savitnici po običaju s gospodom strojnici crkve bosanskje..." ${ }^{123}$

crkvu sv. Petra prihvaća pučko nagađanje da je bila sv. Pavla. Naziv crkva sv. Pavla upotrebljava i MARko Popović, svjestan da nije opravdan pa ističe da je to "samo kao tehnički termin". "Manastir svetog Petra de Campo kod Trebinja", u: GZM, XXVII./ XXVIII., Sarajevo, 1983., str. 313-338 s prilozima i crtežima, posebno bilj. 4. Neke je autore zbunjivalo što papa Klement VI. samostan spominje u jurisdikciji kotorskoga biskupa pa su ga smještali u Boku, jer nisu znali da je poslije progona trebinjskoga biskupa ne samo Trebinjem nego i Humom upravljao kotorski biskup! Konačno, nakon novijih istraživanja samostan neki prozvaše "Petro-Pavlovskim"! Kontroverzni arheolog ĐorĐE JANKOVIĆ: "Pokretni nalazi ranovizantijskog doba iz kasnoantičke krstionice crkva manastira svetih apostola Petra i Pavla kod Trebinja", u: Tribunia, 10, Trebinje, 2003., str. 55-76. Usp. i: "Na putu otkrivanja predanja o crkvi u Trebinju", u: Vidoslov, Trebinje, 2003., božićni broj., str. 151-164; Aleksandar Ratković, "Novi podaci o crkvi svetog ap. Pavla u Trebinju", u: Vidoslov, vaskršnji broj, 2007., str. 221-226.

117 F. ŠIšıć, Letopis, str. 360; V. MošIn, Ljetopis, str. 96; J. Resti, nav. dj., str. 43.

118 Mavro Orbini, Kraljevstvo Slavena, Franjo Šanjek (prir.), Zagreb, 1999., str. 297, 311 (u originalnom izdanju 233, 245); I. OsтолIć, nav. dj., II., str. 541.

119 DAD, Lib. Mal., I., fol 13; Đ. Tošić, Trebinjska oblast, str. 97, 118, bilj. 23.

120 Bit i nauka, pa i samo ime, Crkve bosansko-humskih krstjana nije predmet ove studije, želi se samo konstatirati prisutnost ove specifične zajednice na području Biskupije.

121 Cod. dipl., II., str. 333-334; kopija: Franjo ŠAnjex, Bosansko-humski (hercegovački) krstjani i katarsko-dualistički pokret u srednjem vijeku, Zagreb, 1975., šesta stranica umetka nakon str. 32 .

122 O odnosu srpskih vladara prema herezi: Lazar Mirković, Spisi sv. Save i Stevana Prvo-venčanog, Beograd, 1924., str. 181-182; Milivoje BAšIĆ, Stare srpske biografije, Beograd, 1924., str. 155.

123 Ljubomir Stojanović, Stare srpske povelje i pisma, I/2, Beograd - Sremski Karlovci, 1934., str. 149; Medo Pucić, Spomenici srpski, I., Beograd, 1858., str. 68, 70. 
Šire područje oko spomenutih posjeda Radinovića - Pavlovića i drugu polovicu Konavala držao je moćni Sandalj Hranić, koji je također bio sljedbenik Crkve bosanske. Dubrovnik mu 1405. godine predlaže da posrednik u sukobu između njih bude "lo diedo, che e signor et padre spirituale de la glexia vostra di Bosna". ${ }^{124}$ Njegov sinovac i nasljednik herceg Stjepan Vukčić Kosača, čija je sestra Teodora bila majka braće Pavlovića, određuje da se razmirice u obitelji rješavaju "gospodinom djedom crkve bosanske i 12 strojnikom, među kojimi strojnici bude gospodin gost Radin za života". ${ }^{125}$ Spomenuti Radin je kao krstjanin službovao na dvoru Pavlovića. Kasnije je prešao na dvor hercega Stjepana, gdje je postao starac, pa gost te bio utjecajniji na Hercega i od samih njegovih sinova! ${ }^{126} \mathrm{U}$ službi ovih dviju velikaških porodica bili su i krstjani Vlatko Tumarlić, Tvrdisav, Cernika, Cvjetko, Petko Jeremija, Radovac, Radišin, Divac, zatim starac Radosav, kao i gosti Ma- iša, Dmitar, Gojsav, Radivoj Priljubović, Radosav Bradijević, Radin Seoničanin, Radin Butković, Vuk Radivojević i dr. ${ }^{127}$ Može se, dakle, pretpostaviti da su se krstjani uz potporu spomenutih velikaških porodica brzo širili. Spominje se više njihovih "hiža" na području biskupije: Uskoplje, Bijela, Humsko kod Foče, zatim u Konavlima... ${ }^{128}$ Dubrovčani 1431. godine izjavljuju da su opkoljeni patarenima i manihejima, ${ }^{129}$ ali ta vijest može biti i političko pretjerivanje. Tako u vrijeme ratova Dubrovčani za Radoslava Pavlovića kažu da je opaki i svetogrdni heretik pataren, dokazani neprijatelj i "bič katoličke vjere". ${ }^{130}$ Za hercega Stjepana pišu, također u ratu, da "odrie crkvu konavosku i ne ostavi njoj nego mire", 131 da im je crkve pretvarao u konjušnice, konjima Kristov lik gazio i da su neki svećenici u Župi ubijeni... ${ }^{132}$

Visoka vlastela izgleda nije nasilno širila Crkvu bosansku ${ }^{133}$ jer u vrijeme mira vijesti su bile sasvim drugačije.

124 Citirano prema: M. Perojeviću, Povijest BiH, I., str. 416.

125 LJ. Stojanović, nav. dj., I/2, str. 66-72; S. M. Ćır ković, Herceg Stefan, str. 198-199; Bare Poparić, Tužna povijest hercegove zemlje (1437-1482), Zagreb, 1942., str. 140, bilj. 143.

126 K. JiReČEK, nav. dj., II., str. 81-82.

127 F. Š AnJeK, nav. dj., str. 115-120; D. Mandić, Bosna i Hercegovina, II., str. 154; Ćiro Truhelka, Povijest BiH, I., str. 767-793.

128 Ćiro Truhelka, u: GZM, 1913., str. 373; Vladislav Skarić, u: GZM, 1934., str. 79-82.

129 Jovan Radonić, Dubrovačka akta i povelje 1/1, Beograd, 1934., str. 155 i dr. Usp. i: Mihailo Dinić, Iz dubrovačkog arhiva, III., Beograd, 1967., str. 181-236.

130 József Gelcich - Lajos Thallóczy, Diplomatarium relationuim reipublicae ragusanae cum regno Hungariae, Budapest, 1887., str. 338-341, 514-524.

131 V. Foretić, Povijest Dubrovnika, I., str. 223; M. Perojević, Povijest BiH, I., str. 522.

132 Lj. Stojanović, nav. dj., str. 65; S. Ćirković, Herceg Stefan, str. 155.

133 Opširnije: Ivica Puljıć, "Crkvene prilike u zemljama Stjepana Vukčića Kosače", u: Fenomen 'krstjani' u srednjovjekovnoj Bosni i Hercegovini, Sarajevo - Zagreb, 2005., str. 239-267. 
Sandalj je 1419. godine sudjelovao u procesiji sv. Vlaha. ${ }^{134}$ Zaželio je sagraditi crkvu-zadužbinu na dubrovačkom području "da hvata duši mjesto", ${ }^{135}$ a na dubrovačkom području mogla je biti samo katolička. Herceg Stjepan je u oporuci ostavio Dubrovčanima "naiprvo za moju dušicu" čak tisuću dukata $^{136}$ na slavu i na službu Božju, a ta služba Božja u Dubrovniku također je mogla biti samo katolička. Papa Pavao II. (1464.-1471.) piše Dubrovčanima 1469. godine da nema ništa pobožnije ni na veću slavu Božju, a darovatelju spasonosnije, nego da se taj novac upotrijebi u obranu svete vjere. Tom zgodom papa Hercega zove "pokojnim dragim sinom", kako zove samo pripadnike Katoličke crkve. ${ }^{137} \mathrm{Na}$ dvoru je držao mitropolitu Davida te mu omogućavao da prevodi heretike u pravoslavlje, ali ni Pravoslavna crkva mu ne priznaje pra- vovjernost, kako svjedoči carigradski patrijarh Genadije. ${ }^{138}$

Biskupija je znatnije teritorijalno oštećena kad su Dubrovniku 1419. Sandalj, a 1433. godine ${ }^{139}$ i Pavlovići prodali Konavle, jer su ovi krajevi morali biti još uvijek pretežno katolički.

\section{Duboka kriza u tursko doba}

Turci su već 1386 . godine prodrli do Neretve. Puno stoljeće vlada "metus Turcorum" i bježanje u sigurnije krajeve. Dubrovački senat je 1432. godine silom obustavio migracije na dubrovačko područje, od čega se kasnije odustalo. ${ }^{140}$ Velika nevolja pred osvajanje bilo je savezništvo Turaka s Vlasima, koji hvataju i prodaju Turcima domicilno pučanstvo kao roblje. ${ }^{141} \mathrm{Uz}$ gotove domove izbjeglih katolika otimaju i crkve, a pritisak na preostale katolike da prijeđu na pra-

134 V. Foretić, Povijest Dubrovnika, I., str. 191-195.

135 Ć. Trunhelka, Povijest BiH, I., str. 209-211; M. Perojević, Povijest BiH, I., str. 490; V. Ćorović, Historija Bosne, I., str. 162.

136 Marijan Sivrić, "Oporuka i smrt hercega Stjepana Vukčića Kosače", u: Motrišta, 18, Mostar, 2000., str. 78-84.

137 J. Gelcich - L. Thallóczy, nav. dj., str. 629.

138 Augustin Pavlović, "Katolici i pravoslavni u našim krajevima prema grčkim vrelima 15. stoljeća", u: Croatica christiana periodica, 25, Zagreb, 1991., str. 95-108; F. ŠAnJEK, Bosansko-humski krstjani u povijesnim vrelima, str. 319-323; IsTi, "Crkva bosanska: dualistička sljedba ili evanđeoski ideal zajedništva u duhu pracrkve", u: Kršćanstvo srednjovjekovne Bosne, Studia Vrhbosnensia, IV., Sarajevo, 1991., posebno str. 159-161; Dragoljub Dragojlović, Krstjani i jeretička Crkva bosanska, Beograd, 1987.

139 Ć. Truhelka, Konavoski rat, str. 145-211; V. Foretić, Povijest Dubrovnika, I., str. 190-200. Možda je Dubrovnik darovanjem otoka Molonta htio biskupiji ublažiti gubitke. Đ. Tošıć, Trebinjska oblast, str. 114.

140 DAD, Cons. Rog., V., fol. 57'; Đ. Tošıć, Trebinjska oblast, str. 102, bilj. 63 i str. 130, bilj. 11; Veljan Atanasovski, Pad Hercegovine, Beograd, (1979.), passim.

141 Usp. DAD, Lam. de for. XXXVIII., f. 77, XLI., f. 76 i L., f. 100-101; Đ. Tošıć, Trebinjska oblast, str. 20, s popratnom bilj. 38 na str. 51, zatim str. 23 s popratnom bilj. 64 na str. 52 i str. 133 . 
voslavlje trajao je tijekom cijele turske vladavine. ${ }^{142}$

\subsection{Prilike u biskupiji u prvom stoljeću turske vladavine}

Vijesti o katolicima na području Trebinjske biskupije u vrijeme turskih osvajanja i utvrđenja njihove vlasti iz godine $u$ godinu su sve rjeđe i samo usputne. Tako usput doznajemo da je bilo katolika u Poljicu, jer 1474. godine Ljubisava, kći Miloradova, optužuje muža Ratka Bijeljića Vragančića iz Poljica da ju je istjerao iz kuće "contra omnem sanctionem sacrosanctae romane ecclesie". ${ }^{143}$ Don Vlaho Gabrielis 1488. godine gradi crkvu sv. Barbare u Kočeli ${ }^{144}$ kod Trebinja, što nas ne ostavlja u sumnji kako su katolici bili toliko brojni da im je zatrebala nova crkva. Anonimni mletački izvjestitelj piše u XVI. stoljeću da u dubrovačkom zaleđu ima $12.000 \mathrm{ka}$ tolika, a početkom XVII. stoljeća u svom izvješću Masarechi piše "najmanje" $10.000 .{ }^{145}$ Prigodom imenovanja biskupa Franje zapisano je da Trebinjska biskupija u nevjerničkim krajevima ima "quamplures clericos, et Laicos Christianos". 146 Spominje se u ranim turskim dokumentima uz crkvu sv. Petra u Zavali svećenik "sin Ivke". ${ }^{147} \mathrm{Za}$ crkve na Trebinji i Veljoj Međi kaže se "nema svećenika". Turcima je to bilo neprihvatljivo, jer nema tko plaćati porez pa su crkvene posjede prepuštali pravoslavnim službenicima. ${ }^{148} \mathrm{U}$ rukama katolika ostale su npr. crkva sv. Petra u Kalađurđevićima, sv. Mitra - Dimitrija u Ravnom, sv. Nikole u Rupnom Dolu, sv. Petra u Zavali, sv. Stjepana u Novom i dr. Početkom XVI. stoljeća turske vlasti naređuju rušenje crkava i križeva pokraj putova koji nisu postojali u staro "nevjerničko" vrijeme. ${ }^{149}$ Otada su se, uza skupo plaćene dozvole u Carigradu, mogle samo obnavljati porušene katoličke crkve.

142 Katolici su svako nekoliko godina morali tražiti od sultana fermane da se obrane od pravoslavnoga klera. Usp. Donato Fabianich, Firmani inediti dei sultani di Constantinopoli ai conventi franciiscani e alle autorità civili di Bosnia e Erzegovina, Roma, 1923.; Krunoslav Draganović, Masovni prijelazi katolika na pravoslavlje hrvatskog govornog područja u vrijeme vladavine Turaka, Mostar, 1991., passim.

143 DAD, Lam. de for., XLV., 6', document od 16. VII. 1474. Usp. i Liber Dotum, IV., fol 145', V., fol 45, fol 60, VI., fol 128, VII., fol 42; V. Atanasovski, nav. dj., str. 90, bilj. 31; Đ. Tošıć, Trebinjska oblast, str. 249, bilj. 132.

144 DAD, Diversa notariae, № 68, f. 129.

145 Šme Luubić, "Marijana Bolice Kotoranina. Opis sandžakata skadarskoga", u: Starine, JAZU, XII., Zagreb, 1880., str. 201; Krunoslav Draganović, "Izvješće apostolskog vizitatora Petra Masarecchija o prilikama katol. naroda u Bugarskoj, Srbiji, Srijemu, Slavoniji i Bosni god. 1623. i 1624.", u: Starine, JAZU, XXXIX., Zagreb, 1938., str. 47.

146 D. Farlati, nav. dj., VI., str. 304.

147 A. S. Aličić, nav. dj., str. 488.

148 Popis poreza Vlaha kaze Nevesinje, nedatiran, nastao poslije 1537. godine. Vidi i IvicA PuljIĆ, "Nekoliko svjedočanstava o katoličkoj crkvi sv. Petra u Zavali", u: Isti (prir.), Od Dubrave do Dubrovnika, Humski zbornik, XIII., Neum - Dubrovnik, 2011., str. 321. Posjed crkve sv. Petra u Zavali preuzeo je kaluđer Dragila, I. Puljıć, "Nekoliko svjedočanstava o katoličkoj crkvi sv. Petra u Zavali", str. 326.

149 Hazim ŠABANOvić u ediciji: SKupina AUTORA, Kanuni i kanun-name - za bosanski, hercegovački, zvornički, kliški, crnogorski i skadarski sandžak-Monumenta turcica, I., serija 


\subsection{Trebinjsko-mrkanska bi- skupija "episcopatus titularis"}

Kada je početkom 1464. godine ${ }^{150}$ umro biskup Mihael, papa Pio II. (1458.-1464.) je na trebinjsku biskupsku stolicu premjestio biskupa "barionensis", dominikanca Blaža Dubrovčanina, kome se kao mjesto rezidiranja određuje Dubrovnik. ${ }^{151}$ Ni njegovi nasljednici Donat Georgi (1481.-1492.), Georgius de Cruce (1492.-1513.), Augustin Nalješković (1514.-1527.), Franjo Pucić (1528.1532.), Toma Crijević (1532.-1562.) i Jakov Lukarević (1562.-1575.) ${ }^{152}$ očito nemaju veze $s$ biskupijom čiji naslov nose, $s$ vremenom su postali neke vrste pomoćnih biskupa dubrovačkom nadbiskupu. Zanimljivo je da biskup Kružić 1513. godine u oporuci ostavlja biskupiji kupljenu kuću za 255 dukata u predgrađu Ploče ne "ex debito" nego "ex amoris"! ${ }^{153}$ Konačno prigodom imenovanja biskupa Šimuna Menčetića (1575.-1609.), kardinal Sabellus u konzistoriju ${ }^{154}$ podnosi izvješće u kojemu izričito kaže da je Mrkanska i Trebinjska biskupija na- slovna i da nema uopće brige za duše. Trebinjska je biskupija zaposjednuta od nevjernika i Turaka, a Mrkan je mali pusti školj u dubrovačkoj vlasti. Postojanje biskupa održava se u Dubrovniku samo za sjaj i ukras grada. Biskup Menčetić je prigodom imenovanja dobio dozvolu da zadrži službu dubrovačkoga kanonika, a 1588. godine podnosi izvješće samo o Mrkanskoj biskupiji. ${ }^{155}$

Nekoliko vijesti svjedoče da brigu o katolicima pod Turcima praktično vode svećenici u službi dubrovačkoga nadbiskupa. Krajem XVI. stoljeća isusovac Mancinelli svjedoči da ima nekrizmanih staraca od 90 godina. ${ }^{156}$ U Popovu djeluju svećenici iz samostana u Slanom. Fra Siksto je 1526. godine slavio o Petrovdanu svetu misu s mnoštvom puka u Zavali i Hutovu. ${ }^{157}$ Fra Bazilio je zapisao na margini kamene ploče da su Andrijaševići (dvojica Nikola i Boško) 1574. godine obnovili crkvu Male Gospe u Ravnom, koju je blagoslovio stonski biskup Bonifacije Drkolica, ${ }^{158}$ kao vizitator na turskom području. Poznati

1, Zakonski spomenici, sv. 1, Sarajevo, 1957., str. 19, 31, 56, 66; BRANisLav ĐurĐEv u istom zborniku, str. 31, 43.

150 Sačuvana je njegova oporuka sastavljena 1464. godine kada je i umro. M. Sivrić, Oporuke, str. 82. Nije dakle umro 1456. (B. PandžIć. De dioecesi, str. 89 i bilj. 4).

151 B. PAndžIĆ, De dioecesi, str. 89-90 s bilješkama.

152 D. Farlati, nav. dj., VI., str. 300-307; B. PandžIĆ, De dioecesi, str. 90-94.

153 M. Sivrić, Oporuke, str. 87.

154 D. Farlati, nav. dj., VI., str. 307-308; B. PAndžić, De dioecesi, str. 90-95.

155 Bazılıje PAndžıć, "Trebinjska biskupija u tursko doba", u: Tisuću godina Trebinjske biskupije, Studia Vrhbosnensia, II., Sarajevo, 1988., str. 92.

156 K. Draganović, Masovni prijelazi, str. 38-54, 127; Mujo Korade, "Julije Mancinelli o dubrovačkoj okolici (1575/76)", u: Vrela i prinosi, 16, Zagreb, 1986., str. 133-151.

157 Opširnije: Ivica Puljıć, "Nekoliko svjedočanstava o katoličkoj crkvi sv. Petra u Zavali", str. 306-310.

158 Ivica Puljıć, "Stariji sakralni objekti na području Popova", u: Ravno, Popovo, Humski zbornik, III., Ravno - Zagreb, 1997., str. 151-154 i dr. 
su župnici Popova fra Filip Dobroslavić i don Marko Natali. ${ }^{159}$ U Gracu je župnikovao bezimeni dubrovački svećenik. Tako je očito za održanje katolicizma na ovim prostorima zaslužna isključivo Dubrovačka nadbiskupija, ali i Republika preko svojih legata u Carigradu.

\subsection{Obnova rezidencijalne Trebinjsko-mrkanske biskupije početkom XVII. stoljeća}

Barski nadbiskup fra Toma Medvjedović, rodom iz Orahova Dola, odmah je po imenovanju 1599. godine ${ }^{160}$ pokušao proširiti barsku nadbiskupiju na sva područja pod Turcima. Papa Klement VIII. (1592.-1605.), na molbe iz 1600. i 1604. godine, dopustio mu je da obnavlja utrnule biskupije i prima svećenike-dragovoljce čak i protiv volje njihovih poglavara. $\mathrm{Na}$ našim širim prostorima odlučio je obnoviti antičku naronsku biskupiju sa sjedištem uz crkvu sv. Stjepana u Gabeli. Za vikara u toj naronskoj ili "stjepanskoj" biskupiji postavio je 1605. godine župnika Popova fra Filipa Dobroslavića. U Zažablje je poslao za župnika fra Blaža Gračanina koji je potjerao dubrovačkoga svećenika, krivo ga optužujući u Rimu da je bio oženjen i imao djecu te da je i on bio sin oženjenoga svećenika i počinio zla u puku slična kalvinizmu. ${ }^{161} \mathrm{Na}$ sreću ove klevete demantira pismo domini- kanskoga vikara Hrvatske Danijela Splićanina iz 1589. godine papi Sikstu V. (1585.-1590.) u kome ga moli da se zauzme za katolike Zažablja od uskočkih napada, za koje kaže da su "veoma dobri kršćani i drže pravu vjeru rimsku, a njihov župnik je jedan dubrovački svećenik jer oni graniče $s$ Dubrovčanima, i netom vide svećenika po svojoj mu se velikoj prostodušnosti kao klanjaju, a ovo mogu posvjedočiti jer sam bio više puta kod njih..."162

Pokušaj barskoga nadbiskupa Tome da promijeni crkveni ustroj u Hercegovini imao je pozitivnu posljedicu da je Trebinjsko-mrkanska biskupija ponovno postala rezidencijalnom. Naime, Tomin nasljednik u Baru nije išao njegovim putem pa se pojavio problem koji biskup treba upravljati ovim područjem. Osim toga, 1606. godine imenovan je trebinjsko-mrkanskim biskupom liječnik laik Toma Budislavić kome je Pavao V. (1605.-1621.) dopustio da primi sve redove u roku 6 mjeseci. ${ }^{163}$ Kao liječnik svjetskoga glasa stekao je veliko bogatstvo (liječio poljskoga kralja pa i samoga turskog sultana te dobio od njega "u aparluk" Bobane na području biskupije). Kao laik nije poznavao titularni status biskupije pa je u svom žaru odlučio odmah "svoju siromašnu zaručnicu" uzdići, ostavivši joj u oporuci veliko bogatstvo za utemeljenje kolegija u Dubrovniku da se

159 Ratko Perić, Da im spomen očuvamo, Mostar, 2000., str. 71-72; B. PAndžIć, "Trebinjska biskupija u tursko doba", str. 93.

160 I. Jovović stavlja 1598. kao godinu Tomina nastupa, nav. dj., str. 120-124, 221.

161 B. PANDŽıć, De dioecesi, str. 92-93, 112-113.

162 Stjepan Krasić, "Izvještaj iz 1589. godine", u: Mostariensia, 9, Mostar, 1988., str. 105114.

163 D. Farlati, nav. dj., VI., str. 308-309; B. Pandžı́, De dioecesi, str. 43-51, 95-96. 
u njemu odgajaju mladići za rad u biskupiji i za to zadužio bratovštinu sv. Roka. ${ }^{164}$ Zato je dobio izričitu zabranu da biskupsku službu ne smije vršiti izvan Dubrovnika. Umro je već 1608. godine, ${ }^{165}$ ali je njegov pokušaj vjerojatno utjecao na nasljednika biskupa Ambrozija Gučetića, koga je senat izabrao, a Pavao V. 1609. godine potvrdio, da započne oživljavanje biskupije. On je već sljedeće godine poslao u Rim prvo izvješće u kojemu piše da je počeo vizitirati biskupiju te da mu u Herceg Novom iskazuje poslušnost dvanaest obitelji, a ima i četiri sela u Popovu... Na Mrknu su uzgor i biskupska kuća i uz nju crkva sv. Mihaela kao i crkva Gospe Snježne na obali za koju kaže da je posvećena i sv. Dominiku. U izvješću iz 1613. godine piše da ga priznaju osim vjernika u Herceg Novom i katolici Popova, Orahova (Dola), Bobana i još neki drugi. ${ }^{166}$ Kada je biskup Gučetić 1615. godine premješten za stonskoga biskupa, započeo je, izgleda, sličnu akciju da Stonskoj biskupiji vrati njezinu povijesnu Humsku zemlju pa je nastao spor oko jurisdikcije nad većim dijelom Popova i nad Zažabljem. Dubrovački nadbiskup je naprotiv tražio da mu se vrati jurisdikcija na ovom području. U spor se uključio i novi trebinjsko-mrkanski biskup Krizostom Antić. Fra Blaž se opredijelio za biskupa Antića, posluživši se "glasom naroda", koji je "tvrdio" da su od predaka čuli kako ovim krajevima nitko drugi nije upravljao osim trebinjskoga biskupa i da drugoga ne će prihvatiti niti poštovati. ${ }^{167}$ Biskup Antić i fra Blaž su neko vrijeme složno radili: fra Blaž je uz pomoć naroda organizirao obnovu nekoliko više ili manje porušenih crkava, a biskup ih je Antić blagoslivljao te usput vršio biskupske obrede. Osposobio je i zgrade na Mrkanu za obitavanje te tu povremeno i boravio. ${ }^{168}$ Suradnja je trajala dok se nisu dva domaća biskupa franjevca, biskup Skadra fra Dominik Andrijašević i biskup Lješa fra Benedikt Medvjedović, vratili zamisli barskoga nadbiskupa fra Tome. Službeno su pismom iz 1622. godine opet pokrenuli "obnovu" Naronske ili "stjepanske" biskupije. ${ }^{169}$ Akciju su pojačali kad je Dominik domalo prognan iz Skadra. Fra Blaž se odrekao biskupa Antića te opširnim izvješćem u Rim 1624. godine ${ }^{170}$ ponajviše doprinio stvarnoj uspostavi "stjepanske biskupije". U Rim je opet stiglo "pismo naroda" Neretve, Graca i Popova u kome sad "narod" tvrdi da trebinjsko-mrkanski i makarski

164 M. Sivrić, Oporuke, str. 90-92.

165 O Budislaviću i njegovu kolegiju postoji pozamašna literatura. U novije vrijeme koncizno je o tomu napisao studiju Ratko Perić, "Budislavićev pravovjerni zavod u Dubrovniku", u: Da im spomen očuvamo, str. 401-412.

166 D. Farlati, nav. dj., VI., str. 308-309; B. Pandžıć, De dioecesi, str. 109; Isti, "Trebinjska biskupija u tursko doba", str. 93.

167 D. Farlati, nav. dj., VI., str. 311-312.

168 Isto, str. 310-311.

169 Dominik Mandić, Acta franciscana Hercegovinae, Mostar, 1934., str. 75.

170 Njegovo dragocjeno, ali u mnogim tvrdnjama tendenciozno i pogrješno izvješće objavio je B. PAnDŽIĆ, De dioecesi, str. 112-116. 
biskupi nisu nikad upravljali ovim područjem kako "svjedoče" stogodišnjaci dostojni vjere i povjerenja i kako su to oni čuli od svojih očeva, djedova i pradjedova. ${ }^{171}$ Kongregaciji De propaganda fide, premda je sa svih strana tražila i dobivala izvješća, nije se bilo lako snaći u mnoštvu kontradiktornih tvrdnji pa je donosila kontroverzne odluke te ih opet mijenjala nakon novih informacija. Konačno je stvar raščistila te 1631. godine presudila u korist trebinjsko-mrkanskoga biskupa. ${ }^{172}$ Trebinjsko-mrkanska biskupija je tada utvrdila jurisdikciju sve do Neretve. Biskup Antić poslao je u Rim opširniju povijest biskupije na temelju tada postojećega arhiva koji je stradao u kući izvan grada u vrijeme napoleonskih ratova u kojoj piše da biskupiji pripadaju Dračevica s Risnom, Herceg Novi, Čičevo, Ljubomir, Trebinje, Popovo, Zažablje i "Balaniae" u Nevesinju. ${ }^{173}$ Poslije Morejskoga/Bečkoga rata (1683./1684.1699.), nakon 1703. godine, biskupija je izgubila oslobođeni dio Zažablja u korist makarskoga biskupa. ${ }^{174}$

\section{Novo doba}

\section{Trebinjsko-mrkanske biskupije}

Nakon što je Austro-Ugarska poslije napoleonskih ratova dobila Dalmaciju, pristupila je reorganizaciji crkvenih prilika, pri čemu je i Trebinjsko-mrkanska biskupija bila u sferi njezinih interesa. Poslije smrti biskupa Nikole Ferića nije dopustila imenovanje njegova nasljednika. Bulom Locum beati Petri iz 1828. godine pape Leona XII. (1823.-1829.) Dubrovačka nadbiskupija svedena je na rang biskupije. ${ }^{175}$ Iz bule Apostolici nostri muneris 1839 . pape Grgura XVI. (1831.-1846.), kojom se uprava Trebinjsko-mrkanske biskupije povjerava dubrovačkim biskupima, vidi se da austrijske vlasti nisu birale sredstva do cilja: u buli stoji da je Trebinjska biskupija s 5 župa na području austrijske Dalmacije, a da je Mrkanska bez puka i pod Turcima! ${ }^{176}$

Prigodom odvajanja hercegovačkih franjevaca od Bosne, apostolski vikar fra Rafael Barišić pokušao je u Carigradu isposlovati dozvolu da se Tre-

171 Eusebius Fermendžin, Acta Bosnae, Zagreb, 1892., str. 385-386.

172 Kad je Andrijašević umro u Rimu 1632. godine, Kongregacija piše dubrovačkom nadbiskupu da se njegove stvari predaju trebinjskom biskupu. D. Mandić, Acta franciscana, I., str. 82-115; K. Draganović, "Tobožnja 'stjepanska biskupija - ecclesia stephanensis'", u: Croatia Sacra, IV., Zagreb, 1934., str. 29-58; Ratko Perić, "Sporovi i sporazumi oko 'stjepanske biskupije' (1622.-1631.)", u: Da im spomen očuvamo, Mostar, 2000., str. 384-399.

173 D. Farlati, nav. dj., VI., str. 298.

174 B. Pandžıć. De dioecesi, izvješće biskupa Righia, str. 120.

175 Opširnije: Mile Vidović, Povijest Crkve u Hrvata, Split, 1966., str. 278-282.

176 Na prijevaru je Propagandu upozorio 1856. godine već vizitator o. Basile. Mitar PAPAC, "Trebinjska biskupija sredinom XIX. stoljeća po izvješću apostolskog vizitatora o. Vinka Basila D. I.", u: Vrela i prinosi - Fontes et studia, Sarajevo, 1938., str. 91. 
binjsko-mrkanska biskupija pripoji $\quad$ stro-ugarske vlasti. ${ }^{178}$ Uskoro po okunjegovu vikarijatu, ali se ta opasnost paciji Bosne i Hercegovine austrijske uspjela otkloniti. ${ }^{177}$ Trebinjski je kler vlasti su isposlovale da se Trebinjskood sredine XIX. stoljeća u više navra- mrkanska biskupija preda na upravu ta molio pape da se ispravi neprav- mostarsko-duvanjskom biskupu "doda pa da biskupija dobije vlastitoga nec Sanctitas Sua et Apostolica Sedes biskupa. Odluku kongregacije De aliter decernendum statuerit", što vripropaganda fide pred Hercegovački jedi i danas.

ustanak (1875.-1878.) spriječile su au-

177 Usp. Arhiv trebinjsko-mrkanske biskupije u Arbivu dubrovačke (nad)biskupije, Opći spisi, dokumenti od 5. veljače, 8. i 18. ožujka i 27. lipnja 1846. te u Provikarskom arhivu u Stocu, godište 1846., dokumenti od 5., 26. i 27. veljače i 13. kolovoza.

178 Ivica Puljó́, Hrvati katolici donje Hercegovine i Istočna kriza - Hercegovački ustanak 1875.-1878., Humski zbornik, VII., Dubrovnik - Neum, 2004., str. 84-88. 
Seven centuries from the first mention of the island of Mrkan in the title of the Trebinje bishops

\section{Summary}

The diocese of Trebinje was first mentioned in 1022 in the papal bull of Pope Benedict VIII (1012-1024) from which it could be concluded that the diocese was established at the end of the tenth century. Until the second half of the 12th century it enjoyed freedom whereas with Nemanja's conquest of the coast it was brought to a subordinate position comparing to the Raska (Serbian) orthodoxy. In the mid 13th century, its first bishop was expelled but some time after 1286 the diocese was restored again. The beginning of the 13th century brought the news on the violent persecution of Catholics in the Serbian kingdom. The bishop of Trebinje, who lived in the former Benedictine monastery on the bestowed island of Mrkan, was exiled by King Milutin, at the latest in the war with Dubrovnik from 1217 to 1218. Since then the name Mrkan has been preserved in the title of the Bishop of Trebinje.

Keywords: Trebinje, Mrkan, the Diocese of Trebinje-Mrkan, Dubrovnik. 